\section{OPEN ACCESS}

Edited by:

Michael Rappe,

University of Hawaii at Manoa, USA

Reviewed by:

Brandi K. Reese,

Texas A\&M University-Corpus Christi,

Nathalie Pradel,

Institute of Research

for Development, France

*Correspondence:

Brent C. Christner

xner@ufl.edu

${ }^{\dagger}$ Present address:

Alexander B. Michaud,

Center for Geomicrobiology,

Department of Bioscience,

Aarhus University,

Aarhus, Denmark

${ }^{\ddagger}$ List of participants and their affiliations appear at http://www.wiss ard.org/about/wissard-personnel

Specialty section:

This article was submitted to

Extreme Microbiology,

a section of the journal

Frontiers in Microbiology

Received: 31 May 2016

Accepted: 31 August 2016

Published: 22 September 2016

Citation:

Achberger AM, Christner BC,

Michaud AB, Priscu JC,

Skidmore ML, Vick-Majors TJ

and the WISSARD Science Team (2016) Microbial Community Structure of Subglacial Lake Whillans, West

Antarctica. Front. Microbiol. 7:1457.

doi: 10.3389/fmicb.2016.01457

\title{
Microbial Community Structure of Subglacial Lake Whillans, West Antarctica
}

Amanda M. Achberger ${ }^{1}$, Brent C. Christner ${ }^{1,2,3 *}$, Alexander B. Michaud ${ }^{41}$, John C. Priscu
Mark L. Skidmore

' Department of Biological Sciences, Louisiana State University, Baton Rouge, LA, USA, ${ }^{2}$ Department of Microbiology and Cell Science, University of Florida, Gainesville, FL, USA, ${ }^{3}$ Biodiversity Institute, University of Florida, Gainesville, FL, USA, ${ }^{4}$ Department of Land Resources and Environmental Science, Montana State University, Bozeman, MT, USA, ${ }^{5}$ Department of Earth Sciences, Montana State University, Bozeman, MT, USA

Subglacial Lake Whillans (SLW) is located beneath $\sim 800 \mathrm{~m}$ of ice on the Whillans Ice Stream in West Antarctica and was sampled in January of 2013, providing the first opportunity to directly examine water and sediments from an Antarctic subglacial lake. To minimize the introduction of surface contaminants to SLW during its exploration, an access borehole was created using a microbiologically clean hot water drill designed to reduce the number and viability of microorganisms in the drilling water. Analysis of $16 \mathrm{~S}$ rRNA genes (rDNA) amplified from samples of the drilling and borehole water allowed an evaluation of the efficacy of this approach and enabled a confident assessment of the SLW ecosystem inhabitants. Based on an analysis of 16S rDNA and rRNA (i.e., reverse-transcribed rRNA molecules) data, the SLW community was found to be bacterially dominated and compositionally distinct from the assemblages identified in the drill system. The abundance of bacteria (e.g., Candidatus Nitrotoga, Sideroxydans, Thiobacillus, and Albidiferax) and archaea (Candidatus Nitrosoarchaeum) related to chemolithoautotrophs was consistent with the oxidation of reduced iron, sulfur, and nitrogen compounds having important roles as pathways for primary production in this permanently dark ecosystem. Further, the prevalence of Methylobacter in surficial lake sediments combined with the detection of methanogenic taxa in the deepest sediment horizons analyzed $(34-36 \mathrm{~cm})$ supported the hypothesis that methane cycling occurs beneath the West Antarctic Ice Sheet. Large ratios of rRNA to rDNA were observed for several operational taxonomic units abundant in the water column and sediments (e.g., Albidiferax, Methylobacter, Candidatus Nitrotoga, Sideroxydans, and Smithella), suggesting a potentially active role for these taxa in the SLW ecosystem. Our findings are consistent with chemosynthetic microorganisms serving as the ecological foundation in this dark subsurface environment, providing new organic matter that sustains a microbial ecosystem beneath the West Antarctic Ice Sheet.

Keywords: Antarctica, subglacial lake, subsurface microbiology, biogeochemical cycling, chemosynthetic ecosystem 


\section{INTRODUCTION}

Remote sensing and field surveys have identified $\sim 400$ lakes beneath the Antarctic ice sheet (Smith et al., 2009; Wright and Siegert, 2012), provided evidence for the widespread occurrence of water-saturated sediments (e.g., Studinger et al., 2001), and demonstrated hydrologic connections between certain lakes (Fricker et al., 2007). The abundance of water and availability of metabolic energy sources beneath the ice sheet (Bell, 2008; Smith et al., 2009; Skidmore, 2011; Palmer et al., 2013) supports the possibility for microbial ecosystems and has motivated international exploration efforts in West and East Antarctica (Fricker et al., 2011; Lukin and Bulat, 2011; Ross et al., 2011). Although little information has been available to infer conditions in Antarctica's vast and complex subglacial aquifer, microbial cells inhabiting this biome are estimated at $\sim 10^{29}$ (Priscu et al., 2008), a value similar to global estimates for open ocean waters (Whitman et al., 1998). Fortunately, recent progress in subglacial exploration (Tulaczyk et al., 2014) has provided an opportunity to directly examine the nature, evolution, and biogeochemical contributions of microbial communities at the bed of Antarctica's ice sheet.

Much of the data amassed on subglacial microbial communities has been derived through analyses of subglacial water outflows from alpine and polar glaciers (Skidmore et al., 2005; Cheng and Foght, 2007; Mikucki and Priscu, 2007; Boyd et al., 2011; Hamilton et al., 2013; Dieser et al., 2014) or basal materials retrieved from deep ice boreholes (e.g., Priscu et al., 1999; Lanoil et al., 2009; Christner et al., 2012). This approach has been valuable for providing baseline data and identifying common trends in disparate subglacial ecosystems. For example, there is geochemical and microbiological evidence that subglacial microbes derive their energy through the weathering of bedrock minerals and thus influence subglacial water chemistry (Skidmore, 2011; Mitchell et al., 2013). The prevalence of phylotypes related to species of Thiobacillus and Sideroxydans suggests primary production at the glacier bed may rely on reduced iron and sulfur compounds liberated through glacial comminution and microbiological processes occurring in the sediments or at the bedrock interface (Skidmore et al., 2010; Boyd et al., 2014). Evidence for the activity of methanogenic, methanotrophic, and ammonia oxidizing species has also been provided in several subglacial environments (Boyd et al., 2010, 2011; Dieser et al., 2014), implying these pathways could also play important roles in carbon and nitrogen cycling beneath larger ice masses. Although these pioneering efforts have provided valuable data to generate hypotheses on the structure and function of subglacial microbial ecosystems, their applicability to environments beneath ice sheets has remained uncertain.

Directly sampling sub-ice aquatic environments in a microbiologically clean manner is logistically challenging (Doran et al., 2008; Siegert et al., 2012), requiring strategies to reduce microbial cells associated with the drilling process and minimize exchange between the surface and subglacial environment (Priscu et al., 2013). During January 2013, the Whillans Ice Stream Subglacial Access Research Drilling (WISSARD) Project conducted the first successful sampling of an Antarctic subglacial lake (Christner et al., 2014; Tulaczyk et al., 2014). Christner et al. (2014) reported that planktonic bacteria and archaea in the aerobic water column were at an average concentration of $1.3 \times 10^{5}$ cells $\mathrm{mL}^{-1}$ and morphologically diverse. Molecular analysis of $16 \mathrm{~S}$ rRNA gene sequences amplified from the water column and surficial sediments $(0-2 \mathrm{~cm})$ revealed a rich prokaryotic community consisting of several phylotypes similar to chemosynthetic species that have been observed in alpine and polar glacier environments (e.g., members of Thiobacillus, Sideroxydans, and Methylobacter (Lanoil et al., 2009; Boyd et al., 2014; Dieser et al., 2014). Furthermore, primary and heterotrophic production data revealed that Subglacial Lake Whillans (SLW) contained a metabolically functional microbial community that may be sustained by dark autotrophic activity (Christner et al., 2014).

Here we present a detailed description of SLW's water column and sediment (to depths of $36 \mathrm{~cm}$ ) communities based on analysis of amplified 16S rRNA genes (rDNA) and molecules (rRNA). This approach served the dual role of providing information on microbial community structures while also allowing an assessment of potentially metabolically active taxa and the biogeochemical reactions they are likely to catalyze. Our data provide an initial framework for discerning the diversity and ecology of Antarctic subglacial lake environments, and support the hypotheses that microbial transformations beneath ice masses are driven by chemosynthesis and have global biogeochemical significance (Wadham et al., 2012).

\section{MATERIALS AND METHODS}

\section{Site Description and Drilling Operations}

SLW is centrally located in the lower Whillans Ice Stream (WIS), West Antarctica beneath $\sim 800 \mathrm{~m}$ of ice and has a maximum area of $\sim 60 \mathrm{~km}^{2}$. The water column depth was $\sim 2.2 \mathrm{~m}$ when sampled in January 2013 (Fricker and Scambos, 2009; Christianson et al., 2012; Tulaczyk et al., 2014). Observations of ice surface elevation changes in this region of the WIS have provided data to infer subglacial hydrological conditions and examine their influence on ice sheet behavior (Bell, 2008; Pritchard et al., 2012; Carter et al., 2013). SLW was shown to receive episodic water input from the upper WIS and the neighboring Kamb Ice Stream, and as such, is classified as an active lake (Smith et al., 2009; Wright and Siegert, 2012). Since 2003, SLW has filled and drained three times (Siegfried et al., 2016). The outflow is transported via subglacial channels $\sim 100 \mathrm{~km}$ to the grounding zone and drains into the marine cavity beneath the Ross Ice Shelf (Fricker and Scambos, 2009). At the time of sampling, SLW was at a low stand and filling (Siegfried et al., 2016). The surface sediments of the lake bed were composed primarily of glacial till that was likely deposited during flood events (Hodson et al., 2016), while the deeper sediments contained seawater signatures that linked their origin to past marine intrusions in the region (Christner et al., 2014; Michaud et al., 2016).

During January 2013, a hot water drilling system (Blythe et al., 2014; Burnett et al., 2014; Rack et al., 2014) was used to create $\mathrm{a} \sim 0.6 \mathrm{~m}$ diameter borehole (location $84.240^{\circ} \mathrm{S}, 153.694^{\circ} \mathrm{W}$ ) in 
the ice overlying SLW. The borehole provided direct access to the SLW water column and underlying sediments over a period of 3 days. Details on the scientific operations conducted by WISSARD at SLW are provided in Tulaczyk et al. (2014).

\section{Microbiological Monitoring during Hot Water Drilling}

To minimize the introduction of microbial contamination into SLW during scientific operations, the melted snow and ice used for drilling was sequentially passed through large capacity filters $(2.0$ and $0.2 \mu \mathrm{m})$ and irradiated with UV (185 and $245 \mathrm{~nm}$ ) to remove and kill cells, respectively. Subsequently, the water was heated to $\sim 90^{\circ} \mathrm{C}$ and pumped through $\sim 1 \mathrm{~km}$ of drill hose into the borehole (Supplementary Figure S1A). The WISSARD water treatment system was tested extensively and its effectiveness is described in Priscu et al. (2013).

Water was sampled from various ports in the hot water system during drilling and in the borehole via hydrocast (Supplementary Figure S1A) to assess the cell concentration and microbial diversity of the drill water. Once drilling progressed to a depth of $\sim 210 \mathrm{~m}$ below the surface (mbs), $19 \mathrm{~L}$ of water was collected from an access port located before the filtration and UV systems and designated sample T1P1 (i.e., time point 1, port 1). Simultaneously, an equal volume from the return pump (designated T1P9) that recirculated water from the borehole to the water treatment system was sampled (Supplementary Figure S1A; Rack, 2016). Drilling was paused at a depth of $\sim 700 \mathrm{mbs}$ to allow visual inspection of the borehole and water sampling. A $10 \mathrm{~L}$ Niskin bottle was deployed to retrieve a direct sample of the borehole water from a depth of $672 \mathrm{mbs}$ (Supplementary Figure S1A). After drilling resumed and the borehole reached a depth of $\sim 735 \mathrm{mbs}$, water samples were again collected from ports on the drilling system. Water returning from the borehole was designated T2P9 (time point 2, port 9) and that originating from a port located after the water heater were designated T2P8 (Supplementary Figure S1A). Immediately after collection, cells in the water samples were filter concentrated on $142 \mathrm{~mm}, 0.2 \mu \mathrm{m}$ Supor membrane filters (Pall Corp.) using a peristaltic pump and sterile tubing.

To disinfect the equipment and instrumentation used during borehole operations, $3 \%$ hydrogen peroxide ( $\mathrm{w} / \mathrm{v}$ ) was applied to all surfaces with a pressure sprayer and the cleaned materials were staged in sealed polyethylene bags. The filter housing of the Large Volume Water Transfer System (WTS-LV; McLane Research Laboratories, Inc.) was cleaned between casts by sequential washes with sterile water, $70 \%$ ethanol, and $3 \%$ hydrogen peroxide.

\section{Water Column and Sediment Sampling}

Particulates in the SLW water column were concentrated by filtration in situ using a WTS-LV that was modified for borehole deployment. During $68 \mathrm{~h}$ of borehole operations, the WTS-LV was deployed three times (Tulaczyk et al., 2014). Each cast was made at the approximate middle of the $2.2 \mathrm{~m}$ water column and filtration occurred for $\sim 2 \mathrm{~h}$. Particulates in the water were collected using a custom, modular $142 \mathrm{~mm}$ polyvinyl chloride
(PVC) filter holder and sequentially concentrated on Supor membrane filters (Pall Corp.) with pore sizes of 10, 3, 0.8, and $0.2 \mu \mathrm{m}$. Flow was measured with an analog meter on the WTS$\mathrm{LV}$, and 4.9, 5.3, and 7.2 $\mathrm{L}$ of water was concentrated during the first, second, and third casts, respectively. Immediately upon retrieval from the borehole, the filter housing was transferred to a class 100 laminar flow hood (Labconco) in the field laboratory. The filters were removed from the housing, placed in sterile $142 \mathrm{~mm}$ Petri dishes, and quartered with a sterile scalpel. Each quarter was placed in a $7 \mathrm{~mL}$ cryovial and stabilized by the addition of $5 \mathrm{~mL}$ of RNAlater (Ambion) or DNA buffer solution [40 mM ethylenediaminetetraacetic acid (EDTA) pH 8.0, $50 \mathrm{mM}$ Tris $\mathrm{pH}$ 8.3, $0.73 \mathrm{M}$ sucrose].

A $36 \mathrm{~cm}$ long sediment core was collected using a multicoring device (Uwitec). The core was sectioned at $2 \mathrm{~cm}$ intervals in a class 100 laminar flow hood (Labconco), and 7-15 g from the inner portion of each interval was placed in sterile $60 \mathrm{~mL}$ Nalgene bottles, preserved in either RNAlater or DNA buffer solution, and mixed. Filters and sediments amended with RNAlater were incubated at $4^{\circ} \mathrm{C}$ for $10-12 \mathrm{~h}$ before freezing. All samples were stored at $-80^{\circ} \mathrm{C}$ until analyzed.

\section{Nucleic Acid Extraction, Amplification, and Sequencing}

DNA was extracted from filters and sediment samples using the Power Water and Power Soil DNA Isolation kits (MO BIO Laboratories, Inc.), respectively, according to the manufacturer's protocols. Amplification and sequencing of $16 \mathrm{~S}$ rRNA genes was conducted as previously described (Christner et al., 2014). RNA was extracted from cells on the filters and reverse transcribed into complementary DNA (cDNA) using the method described by Dieser et al. (2014). For sediment samples, $3 \mathrm{~g}$ (wet weight) were centrifuged at 25,000 $\times g$ for $10 \mathrm{~min}$. The supernatant was discarded and the sediment pellet was suspended in $3 \mathrm{~mL}$ of Tris EDTA (TE) buffer (1 mM EDTA, $10 \mathrm{mM}$ Tris; $\mathrm{pH}$ 6.3). The slurry was subsequently processed with the same extraction protocol used for the filters. Procedural blanks that consisted of clean filters were extracted in parallel and served as methodological controls.

Amplification of the V4 region of the 16S rRNA gene was performed in a $50 \mu \mathrm{L}$ volume using 5 units of AmpliTaq Gold DNA Polymerase LD (Invitrogen) and the following components; $1 \times$ PCR Gold Buffer, $3.5 \mathrm{mM} \mathrm{MgCl}_{2}, 10 \mathrm{pmol}$ of each primer (515F and 806R; Caporaso et al., 2012), $200 \mu \mathrm{M}$ deoxynucleotides (dNTPs) and 1.5-5 $\mu \mathrm{L}$ of DNA template (0.02$1 \mathrm{ng}$ ). The polymerase chain reaction (PCR) consisted of a 5-8 min initial denaturation at $94^{\circ} \mathrm{C}$ followed by 35 cycles of amplification under the following conditions: $94^{\circ} \mathrm{C}$ for $45 \mathrm{~s}$, $50^{\circ} \mathrm{C}$ annealing for $90 \mathrm{~s}$, and elongation at $72^{\circ} \mathrm{C}$ for $90 \mathrm{~s}$, with a terminal elongation at $72^{\circ} \mathrm{C}$ for $10 \mathrm{~min}$. Methodological controls and some of the sediment samples were amplified using up to 40 cycles when no or weak amplification was observed after 35 cycles of amplification. PCR products were evaluated using agarose gel electrophoresis and amplicon concentrations were determined using the Quant-iT PicoGreen dsDNA Assay Kit (Life Technologies). Several sediment extractions showed 
poor amplification and were not submitted for sequencing. The amplicons were pooled in equimolar concentrations, and primers and PCR reagents were removed with the MoBio UltraClean PCR Clean-Up Kit. The pooled amplicons were sequenced on an Illumina MiSeq platform that generated $250 \mathrm{bp}$ paired end reads.

\section{Phylogenetic and Statistical Analysis}

Paired end sequence reads from the V4 region of the $16 \mathrm{~S}$ rRNA gene (Caporaso et al., 2012) were assembled into contigs, quality filtered using the mothur phylogenetic analysis pipeline (v1.33.3; Schloss et al., 2009), and aligned with the mothurcompatible version of the SILVA database (v119). Chimeric sequences were identified and removed using the Uchime algorithm (Edgar et al., 2011), as implemented within mothur. All sequences with $\geq 97 \% 16 \mathrm{~S}$ rRNA gene sequence similarity were defined as an operational taxonomic unit (OTU), and a representative sequence for each OTU was classified using the SEED database with the SILVA Incremental Aligner (SINA v1.2.11; Pruesse et al., 2012). Diversity and richness estimations (Shannon, Inverse Simpson, and Chao1) were calculated using mothur on OTU abundance data normalized to the smallest sample dataset (25,904 sequences; Supplementary Table S1). Singletons were removed before further analysis. Abundant OTUs were defined as having a relative abundance $\geq 1 \%$ of the sequences from a given sample. OTUs that were abundant in the drilling and methodological control samples were designated as potential contaminants and not considered as members of the SLW community. Non-metric multidimensional scaling (NMDS) plots were computed within R (v.3.1.2; R Core Team, 2015) on normalized data that was logarithmically transformed prior to calculation of Bray Curtis dissimilarity matrices using the Vegan (decostand and vegdist functions; Oksanen et al., 2013) and labdsv (nmds function; Roberts, 2007) packages. The level of similarity between microbial communities of various sample groups was further evaluated using analysis of molecular variance, implemented within mothur. Sequence data are available in the NCBI Sequence Read Archive under project PRJNA244335.

\section{RESULTS}

\section{Composition of the Abundant Bacterial and Archaeal OTUs in SLW}

The OTU composition and abundances in samples from the water column were significantly different from those of the sediment $(p \leq 0.005)$, with the surficial horizon $(0-2 \mathrm{~cm})$ showing the highest similarity to the lake water (Figure 1). Both the lake water and sediment communities were statistically distinct from those in the drill and borehole water $(p \leq 0.008)$, and grouped distinctly based on NMDS analysis (Figure 1). A detailed description of the microbial assemblages found in the drill system, borehole, and methodological controls are provided in the supplemental material (Supplemental Figure S1B). Overall, the SLW microbial community structure inferred from the analysis of rRNA and rDNA based data were not statistically different from one another $(p=0.12)$.
The vast majority of sequences obtained from the SLW water column and sediments could be taxonomically assigned at the domain level $(<0.2 \%$ were unclassified). The SLW water column was dominated by bacteria, with only 3 and $2 \%$ of the OTUs classifying as Archaea in the rDNA and rRNA libraries, respectively, whereas $<0.3 \%$ of the sediment community was archaeal. The phylum Thaumarchaeota comprised $\sim 98 \%$ of archaeal OTUs within the water column rRNA libraries, while Euryarchaeota represented $85 \%$ of archaeal sequences obtained from the sediments. The most abundant archaeal OTU within the SLW water column (OTU000074) comprised $1.6 \%$ of the rDNA and $0.6 \%$ of the rRNAbased sequences, respectively, and classified within the genus Candidatus Nitrosoarchaeum (Figure 2). The most abundant euryarchaeotal OTU in the rRNA libraries is most closely related to Methanohalophilus levihalophilus (91\% sequence identity) and was only detected in the $34-36 \mathrm{~cm}$ sediment horizon.

Proteobacteria were the dominant phylum in the SLW ecosystem. Water and surficial sediments $(0-2 \mathrm{~cm})$ were primarily comprised of Betaproteobacteria, while the abundance of Gammaproteobacteria generally increased with sediment depth (Supplementary Figure S2). The most abundant OTU (OTU000528; $\sim 8 \%$ rRNA and $\sim 5 \%$ rDNA) in the water column community was $100 \%$ identical to Polaromonas glacialis (Figure 2). Many of the OTUs abundant in the lake were rare $(<0.01 \%)$ in the sediment community, including taxa most closely related to species of Ferriphaselus (96\% identity; OTU000051) and Solitalea (94\%; OTU000093), as well as several poorly classified members of the Proteobacteria and Lentisphaerae (Figure 2). Also prevalent in the lake were several OTUs (OTUs 000073, 000118, and 022091) sharing $\geq 98 \%$ identity to Candidatus Nitrotoga arctica (Figure 2), representing 9 and $13 \%$ of the rRNA and rDNA water sequences, respectively. This taxa was also found in the sediment community (2\% in rRNA and $5 \%$ in rDNA at $0-2 \mathrm{~cm}$ ), but their abundance decreased rapidly with depth (Figure 2).

Phylotypes in the genera Albidiferax, Sideroxydans, Thiobacillus, and Methylobacter were shared between the water column and surficial sediments $(0-2 \mathrm{~cm})$. An OTU (000038) having 99\% identity with Sideroxydans lithotrophicus was the third most abundant OTU in both the water column and 0-2 cm sediment horizon (rRNA; Figure 2). Two OTUs (002673 and 003072) closely related to Albidiferax ferrireducens ( $\geq 99 \%$ identity), were also highly prevalent in the water column (5\% of rRNA and $3 \%$ rDNA sequences) and sediments ( $\sim 1 \%$ of the rRNA and DNA sequences). The Albidiferax-related OTUs also showed a preference based on size, with larger representation in the 10 and $3 \mu \mathrm{m}$ rRNA libraries (Figure 2). Methylobacter(OTU000112) and Thiobacillus-related (OTU000064) taxa were also present in the water column rRNA libraries (2 and 1\%, respectively), but their abundance was $\sim 10$-fold higher in the surficial sediments (0-2 cm; Figure 2).

At sediment depths between 4 and $36 \mathrm{~cm}$, several abundant OTUs in the rRNA libraries (OTUs 000197, 000370, and 000916) most closely related to Smithella propionica ( $\geq 93 \%$ identity) comprised $4 \%$ of the sediment rRNA sequences (Figure 2). Also 


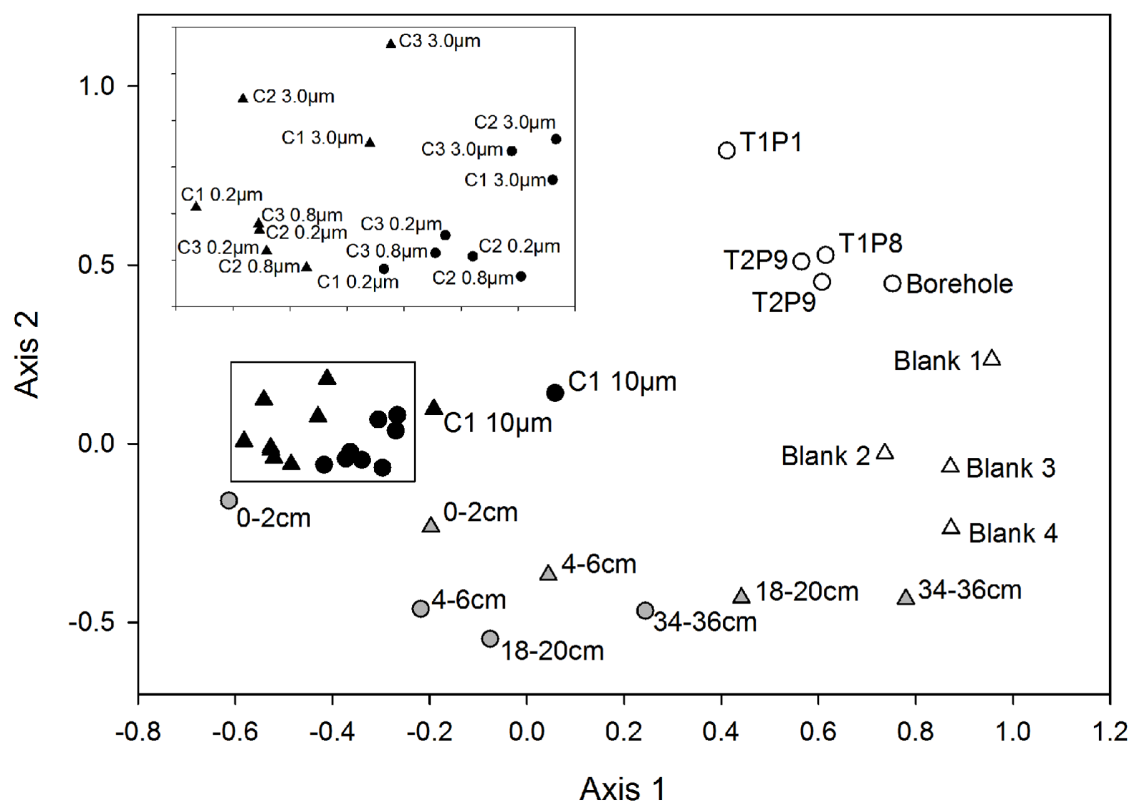

FIGURE 1 | Non-metric multidimensional scaling plot based on OTUs classified from the 16S rRNA and rRNA gene sequences obtained from samples of the drilling water, SLW water column, sediments, and experimental controls. Circles represent rDNA-based sample libraries and triangles represent rRNA-based libraries. Lake water is denoted by black symbols, sediments are gray, and controls are white. Inset contains the $3.0,0.8$, and $0.2 \mu \mathrm{m}$ samples from each water cast outlined with a black box.

abundant in the deeper horizons $(>6 \mathrm{~cm})$ was an OTU $(000564)$ $96 \%$ identical to Ignavibacterium album and one that classified as a member of the Candidate division JS1 (OTU003961; Figure 2). When compared to the water column, the Candidate division JS1, Nitrospirae, and Gammaproteobacteria were generally higher in abundance in the sediments (Supplementary Figure S2).

\section{S rRNA:rDNA Ratios}

The ratio of $16 \mathrm{~S}$ rRNA to rDNA sequence abundance for each OTU identified in SLW was examined. Of the OTUs detected in both the rRNA and rDNA based libraries, 59\% had ratios greater than 1 , and there was a positive correlation (Pearson Correlation; $r=0.77$ ) between the abundance of rRNA and rDNA sequences for individual OTUs (Figure 3A). No correlation was observed between the relative abundance of OTUs and their rRNA:rDNA ratios (Figure 3B).

The relative abundance of $16 \mathrm{~S}$ rRNA to rDNA sequences for a given OTU can be an indication of their potential for metabolic activity (Blazewicz et al., 2013); therefore, OTUs with the largest ratios ( $\geq 5.8$; 99th percentile) were examined in greater detail. Several of the numerically abundant phylotypes (e.g., species of Albidiferax, Methylobacter, Candidatus Nitrotoga, Sideroxydans, and Smithella) were also in the top $1 \%$ of the community based on high rRNA:rDNA ratios (Figure 3C). Rarer taxa, such as those closely related to Desulfatiglans parachlorophenolica (95\% identity; OTU000609) and a poorly classified member of the Chloroflexi (OTU005695), were among the OTUs with the largest rRNA:rDNA abundance ratios observed (38 and 18, respectively).

\section{DISCUSSION}

Antarctic subglacial lakes have been a scientific curiosity since their discovery (Oswald and Robin, 1973). The initial studies on accretion ice from Subglacial Lake Vostok concluded that viable microbes were present in the surface waters of the lake (Karl et al., 1999; Priscu et al., 1999), but due to concerns about sample contamination (e.g., Christner et al., 2005), evidence supporting the habitability of Antarctica's subglacial environment was subject to criticism. More recently, studies have demonstrated the suitability of subglacial environments as ecosystems and shown that liquid water reservoirs at the base of glaciers harbor diverse assemblages of microorganisms (e.g., Skidmore et al., 2005; Boyd et al., 2011; Hamilton et al., 2013; Dieser et al., 2014). However, progress in understanding Antarctic subglacial lake microbiology has been hampered by logistical constraints that make sampling and direct observations challenging. The WISSARD project collected the first pristine water and sediment samples from an Antarctic subglacial lake (Christner et al., 2014), providing an unprecedented opportunity to examine microbial community structure and infer ecosystem processes in an aquatic habitat beneath the West Antarctic Ice Sheet (WAIS).

Conclusions on the composition of SLW microbial communities can be made with confidence given the significant differences they displayed from assemblages in the drilling water and procedural controls (Figure 1; Supplementary Results). With the exception of Janthinobacterium, Tumebacillus, and Herbaspirillum-related OTUs, OTUs identified in the drilling water were rare or absent in lake water samples. Microorganisms that were present in the borehole and drill water may be 


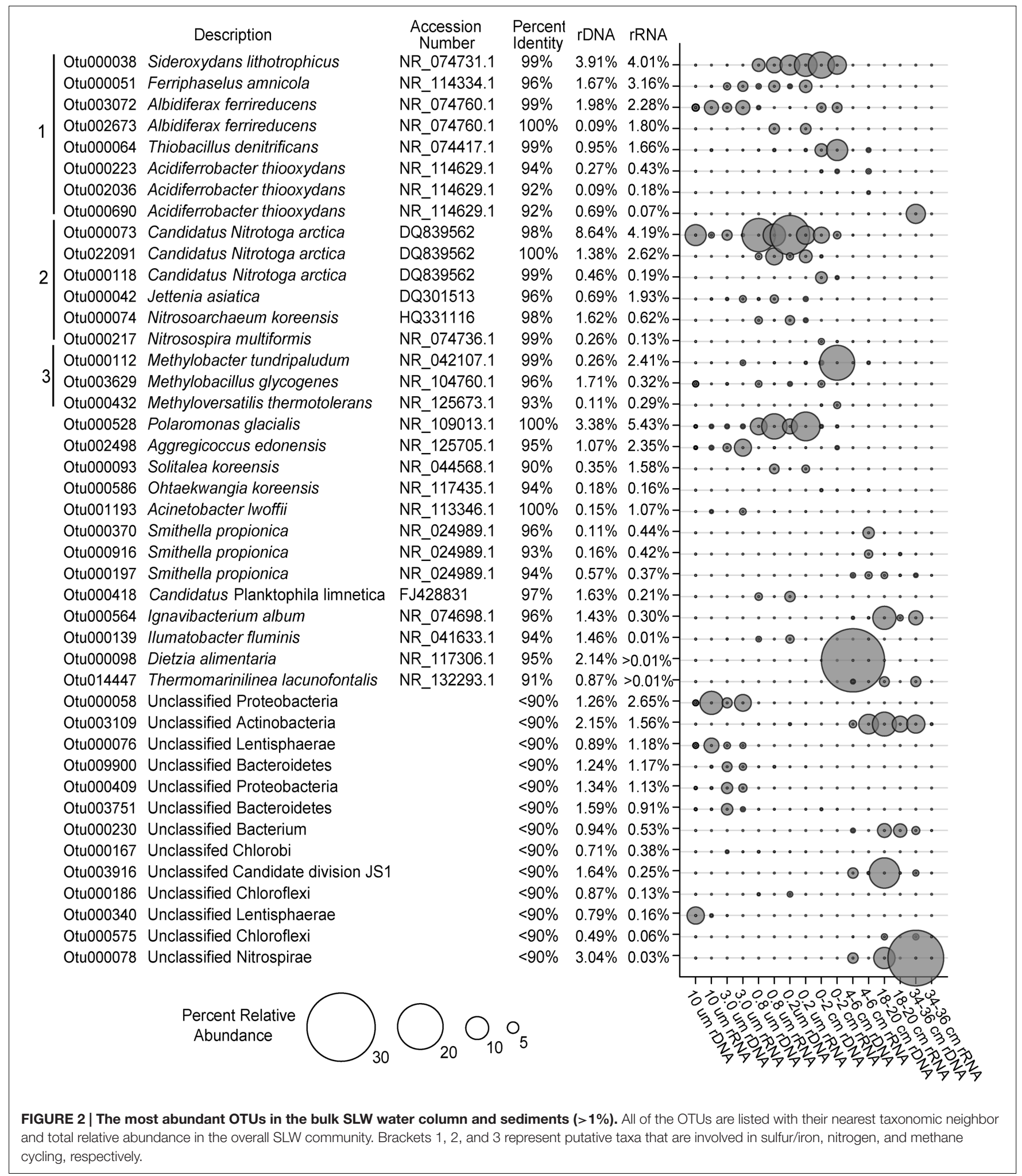

human-based contaminants, derived from the drill system plumbing, and/or have originated from the snow and glacial ice that sourced the water for the drill (Blythe et al., 2014; Rack et al., 2014). The latter is supported by the abundance of OTUs related to Tumebacillus and Janthinobacterium in drilling and borehole water, as these taxa have been frequently identified in polar environments (e.g., Steven et al., 2008; Kim et al., 2012). Alternatively, the presence of OTUs related to 
A

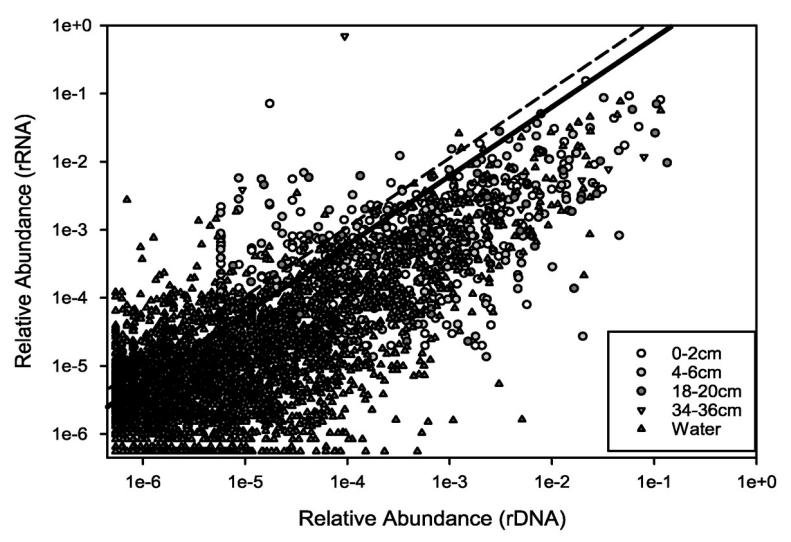

Description

Otu002673 Albidiferax ferrireducens Otu000609 Desulfatiglans parachlorophenolica Otu000380 Sideroxydans lithotrophicus Otu000690 Acidiferrobacter thiooxydans Otu013742 Desulfatibacillum alkenivorans Otu022106 Ectothiorhodospira mobilis Otu000279 Candidatus Nitrotoga arctica

2 Otu002533 Candidatus Nitrotoga arctica Otu000583 Brocadia fulgida

3| Otu000112 Methylobacter tundripaludum Otu002498 Aggregicoccus edonensis Otu001193 Acinetobacter Iwoffii Otu000370 Smithella propionica Otu000733 Byssovorax cruenta Otu000221 Sphingomonas aquatilis Otu002195 Solitalea canadensis Otu001065 Erythrobacter pelagi Otu010260 Syntrophus aciditrophicus Otu008210 Lautropia mirabilis Otu025293 Labilithrix luteola Otu000307 Smithella propionica Otu006794 Tabrizicola aquatica Otu001312 Unclassified Chlorobi Otu005695 Unclassified Chloroflexi Otu015663 Unclassified Bacteria Otu016841 Unclassified Bacteria Otu024095 Unclassified Armatimonadetes Otu034306 Unclassified Bacteria

\section{Accession} Number NR_074760.1 NR_126176.1 NR_074731.1 NR_114629.1 NR_074962.1 NR_125567.1 DQ839562 DQ839562 NR_042107.1 NR_125705.1 NR_113346.1 NR_024989.1 NR_042341.1 NR_113867.1 NR_074099.1 NR_117936.1 NR_102776.1 NR_104897.1 NR_126182.1 NR_024989.1 NR_117979.1
B

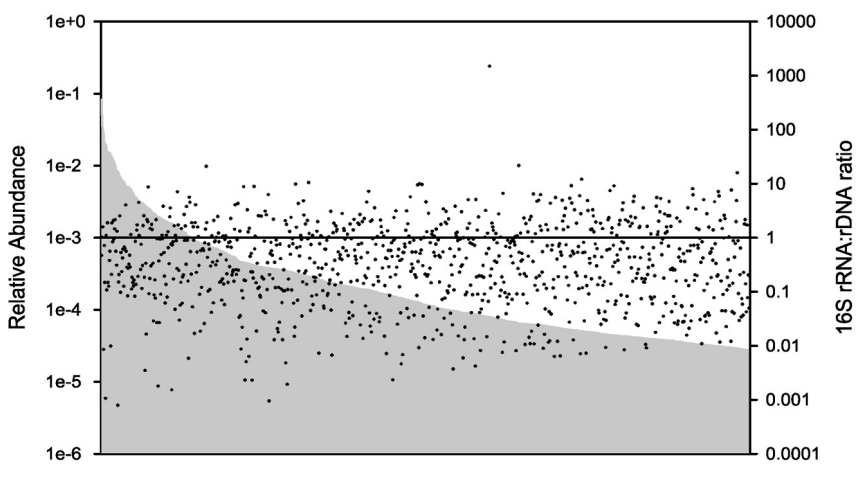

C LAQJ01000287

Percent Identity rDNA rRNA $100 \% \quad 0.08 \% \quad 1.67 \%$ $95 \% \quad 0.03 \% \quad 0.31 \%-$ $98 \% \quad 0.01 \% \quad 0.12 \%-$ $92 \% \quad 0.70 \% \quad 0.07 \%$ $97 \%<0.01 \% \quad 0.02 \%$ $93 \%$ $98 \%$ $99 \%$ $94 \%$ $99 \%$ $95 \%$ $100 \%$ $96 \%$

$90 \%$

$100 \%$ $92 \%$ $100 \%$ $96 \%$

$96 \%$

$95 \%$

$93 \%$

$99 \%$

$<90 \%$

$<90 \%$

$<90 \%$

$<90 \%$

$<90 \%$

$<90 \%$
$0.01 \% \quad 0.02 \%$

$0.08 \% \quad 0.15 \%$

$0.01 \% \quad 0.12 \%$

$0.09 \% \quad 0.09 \%$

$0.26 \% \quad 2.24 \%$

$1.01 \% \quad 2.18 \%$

$0.14 \% \quad 0.99 \%$

$0.11 \% \quad 0.41 \%$

$0.05 \% \quad 0.40 \%$

$0.03 \% \quad 0.30 \%$

$0.04 \% \quad 0.24 \%-$

$0.02 \% \quad 0.14 \%$

$0.04 \% \quad 0.06 \%$

$0.01 \% \quad 0.03 \%$

$<0.01 \% \quad 0.03 \%$

$<0.01 \% \quad 0.02 \%$

$<0.01 \% \quad 0.02 \%$

$0.04 \% \quad 0.10 \%$

$0.02 \% \quad 0.07 \%$

$0.01 \% \quad 0.02 \%$

$<0.01 \% \quad 0.02 \%$

$0.01 \% \quad 0.01 \%$ $0.00 \% \quad 0.01 \%$

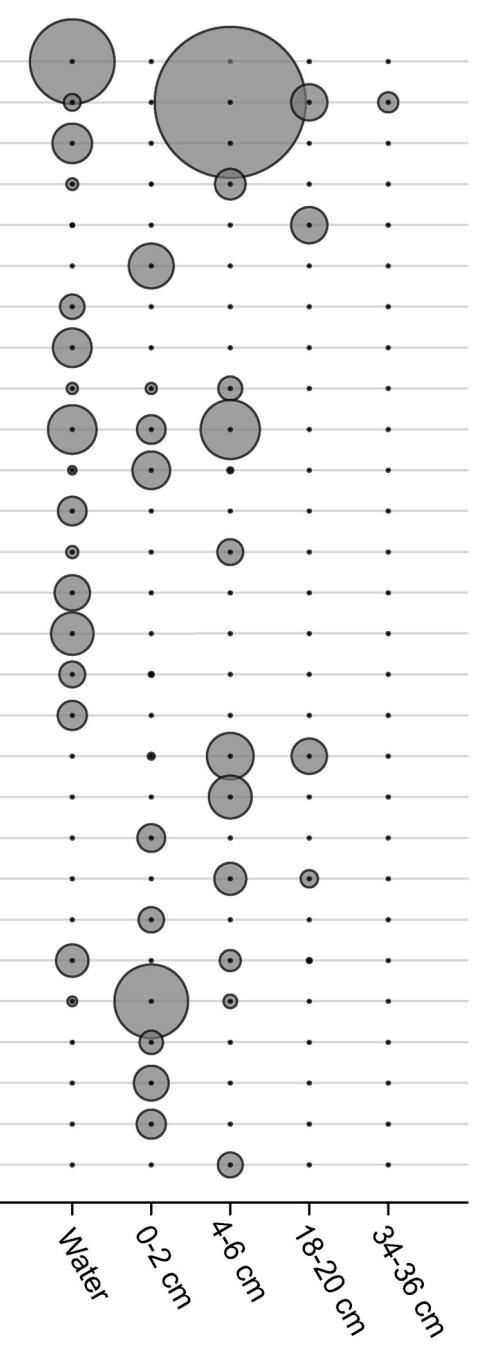

FIGURE 3 | The ratio of 16 S rRNA to rDNA sequences obtained from the SLW molecular data. (A) The relative abundance of individual OTUs in rRNA versus the rDNA sequence data. The black line denotes those OTUs in the top 1\% (ratio of 5.8) while those above the hashed line represent outliers (ratio >10.7). (B) The rank abundance of OTUs (gray), based on 16S rDNA data, and their rRNA:rDNA ratios denoted as black dots. The horizontal black line denotes an rRNA:rDNA ratio of 1 . (C) List of the top $1 \%$ of OTUs with rRNA:rDNA ratios $\geq 5.8$, identified by their nearest taxonomic neighbor. Bracket designations are the same as Figure 2 . 
Herbaspirillum, a bacterial genus that frequently contaminates DNA extraction kits (Salter et al., 2014), may be an artifact of laboratory contamination. Determining the conclusive source of the Herbaspirillum phylotypes is complicated by the fact that limnological studies of surface Antarctic lakes have identified these taxa as bona fide members of the bacterioplankton communities (Pearce et al., 2003; Kuhn et al., 2014). Given these uncertainties, all of the OTUs discussed above were not considered to be members of the SLW community.

In the absence of light and photosynthetic activity, chemolithoautotrophic species may play a crucial role in carbon cycling through the generation of new organic carbon for the subglacial ecosystem. Christner et al. (2014) concluded that rates of $\mathrm{CO}_{2}$ fixation in samples from the SLW water column were sufficient to support heterotrophic production. Given that the waters of SLW are predominantly derived from glacial melt, the bulk of nutrients needed to fuel primary production and support the ecosystem are likely sourced from subglacial sediments that contain relict marine organic matter deposits which are widespread beneath this portion of the WAIS (Wadham et al., 2012; Christner et al., 2014). Hence, the underlying geology and historical connection to the Ross Sea was expected to strongly influence the structure and metabolic function of microorganisms inhabiting the SLW ecosystem through nutrient input.

Similar to other subglacial environments (Christner et al., 2001; Skidmore et al., 2005; Lanoil et al., 2009; Hamilton et al., 2013; Dieser et al., 2014), the microbial species of SLW were largely composed of Proteobacteria, Actinobacteria, Bacteroidetes, and Firmicutes (Supplementary Figure S2), and also contained members of the Nitrospirae, Chloroflexi, Chlorobi, Thaumarchaeota, and Candidate Division JS1 phyla (Supplementary Figure S2). The most abundant taxa in SLW (Polaromonas, Sideroxydans, and Thiobacillus) were closely related to sequences characterized from sediment cores recovered from beneath the neighboring Kamb Ice Stream (Lanoil et al., 2009), while Methylobacter, Albidiferax, Candidatus Nitrotoga, and Thaumarchaeota species have been shown to be prevalent in subglacial outflows, basal ice, permafrost, and polar waters (Alawi et al., 2007; Cheng and Foght, 2007; Alonso-Sáez et al., 2011; Dieser et al., 2014; Doyle, 2015). The widespread distribution of these taxa in cold environments suggests an inherent tolerance of conditions in the cryosphere, and that they may serve important ecological functions in the subglacial habitat.

The relationship between abundances of sequenced $16 \mathrm{~S}$ rRNA molecules and genes has been used as a means to assess the metabolic activity of individual taxa (e.g., DeAngelis et al., 2010; Jones and Lennon, 2010; Campbell et al., 2011; Dieser et al., 2014). Although cellular ribosome concentration correlates positively with growth rate, the interpretation of rRNA:rDNA ratios in natural communities is more complex because the relationship is not uniform for all species (Blazewicz et al., 2013) and may require a fundamentally different interpretation for oligotrophic versus copiotrophic lifestyles (Lankiewicz et al., 2015). In light of these uncertainties, high 16S rRNA abundance and rRNA:rDNA ratios were evaluated to specifically identify outliers in the SLW community data. The OTUs identified through this analysis are inferred to have the greatest potential for metabolic activity within the community and thus most likely to be influencing biogeochemical transformations in SLW at the time it was sampled. The positive correlation between the abundance of rRNA and rDNA in the SLW OTUs (Figure 3A) supported that taxa abundant in the rDNA data were ecologically important and unlikely to represent dead cell populations. Rank abundance of the taxa did not correlate with the rRNA:rDNA ratio (Figure 3B), suggesting that abundance per se was not a good predictor for potential metabolic activity. Although assumptions about metabolic function based on short 16S rRNA gene fragments are tenuous, many of the numerically abundant (Figure 2) and rare OTUs (Figure 3C) with large rRNA:rDNA ratios $(>5.8$; Figure 3C) were phylogenetically related to bacterial and archaeal species that use reduced nitrogen, iron, and sulfur compounds or $\mathrm{C} 1$ compounds as primary electron donors (Figure 4).

Geochemical analysis of the dissolved inorganic nitrogen pool in the SLW water column showed that it was comprised primarily of ammonium $\left(\sim 2.4 \mu \mathrm{mol} \mathrm{L}^{-1}\right)$ and nitrate $\left(0.8 \mu \mathrm{mol} \mathrm{L}^{-1}\right)$, with $\Delta^{17} \mathrm{O}-\mathrm{NO}_{3}{ }^{-}$values $(-0.1$ to $0.2 \%)$ indicating in situ nitrification (Christner et al., 2014). The potential for nitrification was also supported by the abundance of taxa classifying within the Thaumarchaeota (Supplementary Figure S2; Figure 3), a ubiquitous clade containing chemolithotrophic (Könneke et al., 2005) and mixotrophic (Qin et al., 2014) archaea that derive energy from ammonia oxidation. Water column OTUs related to the ammonia oxidizing archaea (AOA) were predominately found as cell populations that passed through $3.0 \mu \mathrm{m}$ pores and were primarily retained on the 0.8 and $0.2 \mu \mathrm{m}$ filters (Figure 2), which agreed well with individual cell sizes reported for this group $(<1 \mu \mathrm{m}$, Könneke et al., 2005). The AOA were 1.6and 14-times (rRNA and rDNA, respectively) more abundant than known ammonia oxidizing bacterial (AOB) genera in the water column; however, the abundance of AOA quickly diminished with sediment depth, while the AOB increased (55fold higher in 0-2 cm rRNA, Figures 2 and 4). The most abundant AOB-related OTU in the sediments had 99\% sequence identity with Nitrosospira multiformis (Figure 2). AOA have been found to outcompete $\mathrm{AOB}$ in environments with low ammonium concentrations $(<1 \mu \mathrm{M})$, presumably due to the higher affinity of their ammonia monooxygenase for substrate (Martens-Habbena et al., 2009). This fact may explain the distribution of AOA and AOB in SLW, as ammonium was 40times more abundant in sediment pore waters than in the lake (Vick-Majors, 2016). Further, SLW contained abundant and rare OTUs with large rRNA:rDNA ratios that were related to the anaerobic ammonia oxidizing bacteria (Figure 4) Candidatus Jettenia asiatica (OTU000042; Figure 2; Hu et al., 2012) and Brocadia fulgida (OTU000583; Figure 3C; Kartal et al., 2008), respectively. These microorganisms may serve an important role in nitrogen removal within the sediments during conditions of water column hypoxia.

With only one known exception (i.e., van Kessel et al., 2015), the second step of nitrification is catalyzed by a physiologically distinct group of microorganisms that oxidize nitrite to nitrate. Based on the SLW water column data, we conclude that this reaction is probably carried out by a group of Betaproteobacteria 


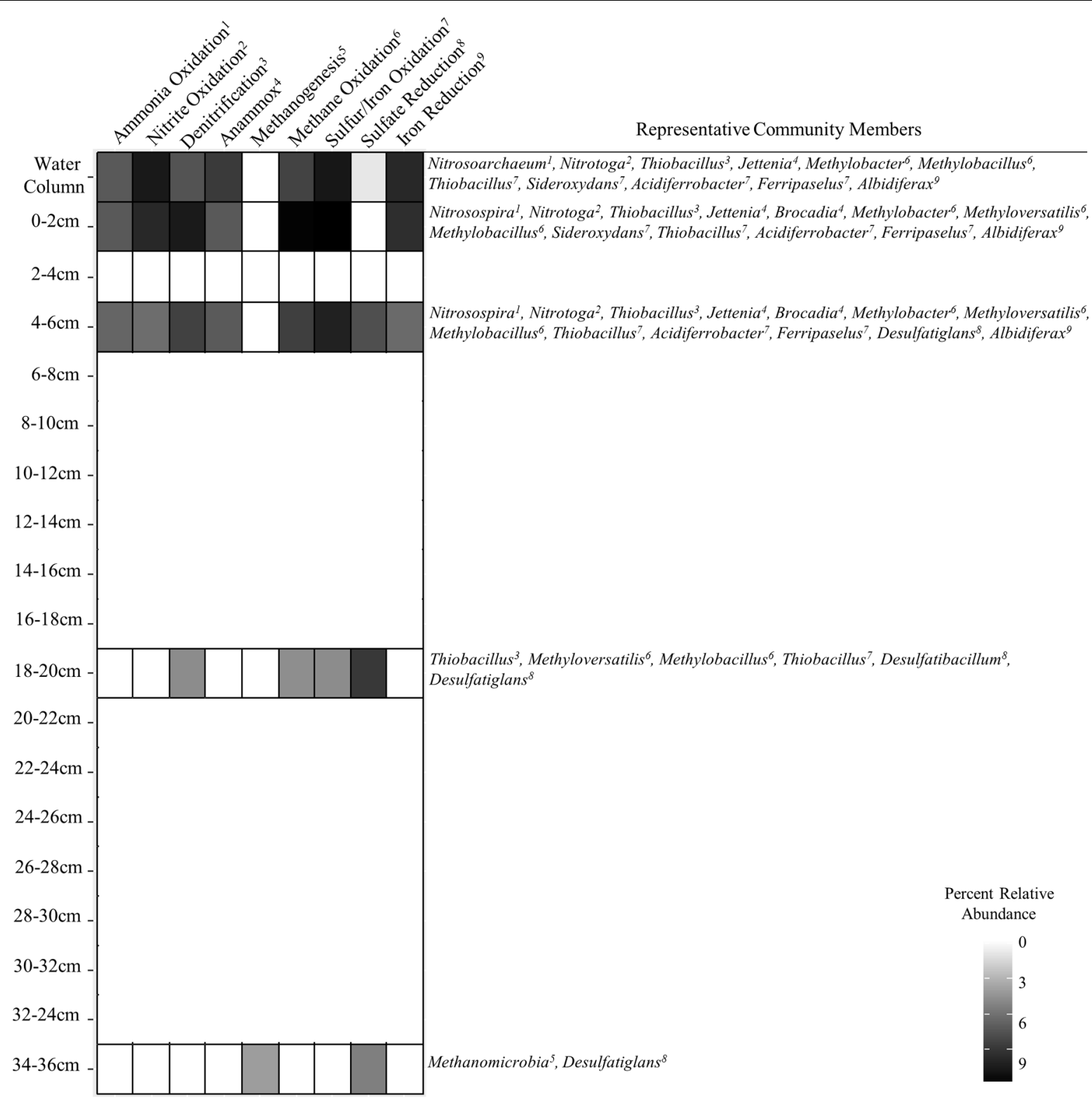

FIGURE 4 | Heat plot showing the occurrence of various putative metabolic functions in SLW inferred from 16S rRNA phylogenetic associations and sequence abundances of important community members.

closely related to Candidatus Nitrotoga arctica, a nitrite-oxidizing isolate from Siberian permafrost (Alawi et al., 2007; Figure 4). OTUs related to Candidatus Nitrotoga were highly abundant in the water column $(\sim 10 \%$ rRNA $)$ and surficial sediment $(0-2 \mathrm{~cm} ; 3.8 \%$ rRNA; Figure 4). Also prevalent within the surficial sediments $(0-6 \mathrm{~cm})$ were OTUs closely related to Thiobacillus denitrificans (99\% sequence identity; Figures 2 and 4), a microorganism with the capacity to use inorganic sulfur compounds or $\mathrm{Fe}^{2+}$ as an electron donor via aerobic respiration or denitrification (Beller et al., 2006).

Studies of subglacial sediments from alpine glaciers (e.g., Skidmore et al., 2005; Boyd et al., 2014; Harrold et al., 2016) and the WAIS (Lanoil et al., 2009) have provided evidence that sulfide and iron oxidation are microbially mediated weathering processes that occur at the bed. Boyd et al. (2014) inferred microbial pyrite oxidation beneath the Robertson Glacier based on geochemical and functional gene analysis, concluding that it may contribute to subglacial primary production. Within SLW's pyrite containing sediments (Michaud et al., 2016), species of Sideroxydans, Ferriphaselus, and Albidiferax (Figures 2-4; Kato et al., 2014) could participate in iron cycling. A. ferrireducens is a heterotrophic, facultative anaerobe capable of coupling the reduction of $\mathrm{Fe}^{+3}$ to the oxidation of organic compounds such as acetate (Finneran et al., 2003), which was $\sim 1 \mu \mathrm{M}$ in the 
SLW water column (Christner et al., 2014; Figure 4). Albidiferaxrelated OTUs were found within the surficial sediments, but in the water column, the majority were observed on the 10 and $3.0 \mu \mathrm{m}$ filter size fractions, consistent with the size reported for the type strain (3-5 $\mu \mathrm{m}$ filaments; Finneran et al., 2003) and/or attachment to water column suspensoids. Although iron reduction is thermodynamically unfavorable in the oxic water column, members of Albidiferax may be associated with anaerobic microhabitats within large suspended sediment particles as has been found in marine snow aggregates (e.g., Stief et al., 2016). It is notable that members of this genera have also been found abundant in other glacier ecosystems, including basal ice facies from the Matanuska Glacier, Alaska and periglacial streams near Thule, Greenland (Doyle, 2015).

Sequences related to the adenosine- 5 -phosphosulfate reductase $(a p r A)$ gene, a key enzyme involved in sulfur redox chemistry, of Sideroxydans and Thiobacillus species were detected in SLW sediments (Purcell et al., 2014). Purcell et al. (2014) used quantitative PCR and estimated $0.084(28-34 \mathrm{~cm})$ to $9.2 \times 10^{5}$ $(0-4 \mathrm{~cm})$ aprA gene copies per gram of wet SLW sediment, which represented from $0.9 \%(28-34 \mathrm{~cm})$ to $15 \%(0-4 \mathrm{~cm})$ of the $16 \mathrm{~S}$ rRNA gene copies that were also detected. This is consistent with our rDNA analysis which showed that OTUs related to the sulfur oxidizing species Sideroxydans and Thiobacillus accounted for $18 \%$ of rDNA sequences in the $0-2 \mathrm{~cm}$ sediment horizon (17\% rRNA), decreasing to $0.01 \%$ at a depth of $34-36 \mathrm{~cm}(0 \%$ rRNA; Figure 2). Members of these genera were also inferred to be highly abundant in the SLW water column (OTUs000038 and 000064; Figure 2) and had large rRNA:rDNA ratios (OTU000380; Figures 3C and 4). The activity of sulfide oxidizing microorganisms within SLW sediments is further supported by the excesses of crustally derived sulfate observed in the upper $15 \mathrm{~cm}$ of the sediments (Michaud et al., 2016). Purcell et al. (2014) also measured low rates of sulfate reduction in laboratory experiments with SLW sediments. Although known sulfate reducing bacteria were rare in the SLW sediment community, OTUs related to the genera Desulfatiglans and Desulfatibacillum had high rRNA:rDNA ratios in the 4-6 and 16-18 cm sediment horizons, consistent with their potential to conduct sulfate reduction in the SLW sediments if redox conditions within the lake become favorable (Figure 4). Nonetheless, sulfate profiles in the sediment porewaters suggested sulfate reduction was not an active process in the upper $36 \mathrm{~cm}$ of the sediments (Michaud et al., 2016). Consequently, the in situ function of these organisms is unknown.

The basal sediments beneath ice sheets may harbor globally significant reservoirs of organic matter and be methane sources to the atmosphere (Wadham et al., 2008). Wadham et al. (2012) estimated a methane reservoir of $\sim 10 \mathrm{Pg} C$ beneath the WAIS, where thick organic rich sediments combined with low temperature and high pressure would promote methane hydrate storage. Methanogenesis has been reported in a number of subglacial environments (Boyd et al., 2010; Stibal et al., 2012a,b), including the bed of the Greenland Ice Sheet (Christner et al., 2012; Dieser et al., 2014). In the sediment core analyzed for this study, OTUs related to methanogenic archaea were rare $(0.1 \%)$ and only detected in the lowest sediment depth analyzed
$(34-36 \mathrm{~cm})$. This coupled with measurements of methane in sediment pore water suggests that methanogenic populations and activity may have been more prevalent in deeper portions of SLW's sediments (Michaud, 2016; Figure 4). An OTU (000112) closely related to the type I methanotroph, Methylobacter tundripaludum ( $99 \%$ identity), was $\sim 10$-fold lower in the water column than in the $0-2 \mathrm{~cm}$ sediment rRNA where it represented $\sim 15 \%$ of the sequences (Figure 2). Dieser et al. (2014) identified a similar phylotype of Methylobacter that was inferred to be responsible for methane oxidation $\left(320 \mathrm{nM} \mathrm{CH}_{4} \mathrm{~d}^{-1}\right)$ in subglacial water outflows at the western margin of the Greenland Ice Sheet. The presence of active methanotrophy in SLW was supported not only by the high abundances of methanotrophrelated OTUs and their large rRNA:rDNA ratios (Figure 3C), but also by geochemical and isotopic data which showed a significant decrease in methane concentration between the surficial sediments $(0-2 \mathrm{~cm})$ and the water column concurrent with a positive shift in the $\delta^{13} \mathrm{C}^{-\mathrm{CH}^{4}}$ (Michaud, 2016). Together, these results imply that microbial methane oxidation may serve a role as a substantial methane sink beneath the WAIS. The effect of subglacial methane release to the atmosphere during ice sheet wastage is estimated to be significant (e.g., Wadham et al., 2012), but such efforts have not considered aerobic methane oxidation as an aspect of carbon cycling beneath ice masses. Our data and those of Dieser et al. (2014) imply that bacterial methane consumption could be a significant methane sink and pathway for primary production in portions of the subglacial hydrological system where methane and oxygen coexist.

\section{CONCLUSION}

There is a lack of fundamental information on the microbial biomes at the base of polar ice sheets because accessing these subglacial environments in a clean, environmentally conscious way is technically and logistically challenging. The WISSARD project at SLW provided the first opportunity to examine the limnology and ecology of an Antarctic subglacial lake, revealing a chemosynthesis-based community comprised of bacteria and archaea, with no conclusive evidence for the presence of eukaryotic species (Christner et al., 2014; Achberger, 2016). The members of SLW's microbial community appear to derive their nitrogen, iron, sulfur, and carbon compounds from mineral weathering and relict organic matter in the sediments (Figure 4; Michaud et al., 2016), but various nutrients may be actively cycled in SLW and the interconnected WIS subglacial hydrologic system. At present it is unclear how representative the SLW microbial ecosystem is of other lakes in this region or to the many hundreds of others beneath the Antarctic ice sheet. However, taxa phylogenetically related to many of the dominant OTUs present in SLW have been previously observed in other icy subsurface environments, raising possibilities for microbial biogeographical studies of specific taxa endemic to the polar regions. Most species inhabiting the SLW ecosystem were distinct from those entrapped in the overlying glacial ice (i.e., the water melted for drilling), implying that microbial inocula for the lake is derived from another source. Hence, microorganisms may enter 
into SLW as plankton or attached to particles that are transported by subglacial water source from more internal regions of the Antarctica continent.

\section{MEMBERS OF THE WISSARD SCIENCE TEAM}

W. Adkins, Louisiana State University, Baton Rouge, USA; S. Anandakrishnan, Pennsylvania State University, University Park, USA; C. Barbante, Ca'Foscari University of Venice, Venice, Italy; G. Barcheck, University of California, Santa Cruz, USA; L. Beem, University of California, Santa Cruz, USA; A. Behar, Arizona State University, Tempe, USA; M. Beitch, University of California, Santa Cruz, USA; R. Bolsey, University of California, Santa Cruz, USA; C. Branecky, University of California, Santa Cruz, USA; S. Carter, Scripps Institution of Oceanography, La Jolla, USA; K. Christianson, St Olaf College, Northfield, USA; R. Edwards, Montana State University, Bozeman, USA; A. Fisher, University of California, Santa Cruz, USA; H. Fricker, Scripps Institution of Oceanography, La Jolla, USA; N. Foley, University of California, Santa Cruz, USA; B. Guthrie, Northern Illinois University, DeKalb, USA; T. Hodson, Northern Illinois University, DeKalb, USA; R. Jacobel, St Olaf College, Northfield, USA; S. Kelley, Montana State University, Bozeman, USA; K. Mankoff, University of California, Santa Cruz, USA; E. McBryan, Arizona State University, Tempe, USA; J. Mikucki, University of Tennessee, Knoxville, USA; A. Mitchell, Aberystwyth University, Aberystwyth, UK; R. Powell, Northern Illinois University, DeKalb, USA; A. Purcell, University of Tennessee, Knoxville, USA; D. Sampson, University of California, Santa Cruz, USA; R. Scherer, Northern Illinois University, DeKalb, USA; J. Sherve, Montana State University, Bozeman, USA; M. Siegfried, Scripps Institution of Oceanography, La Jolla, USA; S. Tulaczyk, University of California, Santa Cruz, USA.

\section{REFERENCES}

Achberger, A. M. (2016). Structure and Functional Potential of Microbial Communities in Subglacial Lake Whillans and at the Ross Ice Shelf Grounding Zone, West Antarctica. Ph.D. thesis, Louisiana State University, Baton Rouge, LA.

Alawi, M., Lipski, A., Sanders, T., and Spieck, E. (2007). Cultivation of a novel coldadapted nitrite oxidizing betaproteobacterium from the Siberian Arctic. ISME J. 1, 256-264. doi: 10.1038/ismej.2007.34

Alonso-Sáez, L., Andersson, A., Heinrich, F., and Bertilsson, S. (2011). High archaeal diversity in Antarctic circumpolar deep waters. Envrion. Microbiol. Rep. 3, 689-697. doi: 10.1111/j.1758-2229.2011.00282.x

Bell, R. E. (2008). The role of subglacial water in ice-sheet mass balance. Nat. Geosci. 1, 297-304. doi: 10.1038/ngeo186

Beller, H. R., Chain, P. S., Letain, T. E., Chakicherla, A., Larimer, F. W., Richardson, P. M., et al. (2006). The genome sequence of the obligately chemolithoautotrophic, facultatively anaerobic bacterium Thiobacillus denitrificans. J. Bacteriol. 188, 1473-1488. doi: 10.1128/JB.188.4.14731488.2006

Blazewicz, S. J., Barnard, R. L., Daly, R. A., and Firestone, M. K. (2013). Evaluating rRNA as an indicator of microbial activity in environmental communities: limitations and uses. ISME J. 7, 2061-2068. doi: 10.1038/ismej.2013.102

\section{AUTHOR CONTRIBUTIONS}

All authors contributed to the study design, acquisition of samples, and writing of the manuscript. The generation and analysis of molecular data was conducted by AA.

\section{ACKNOWLEDGMENTS}

The Whillans Ice Stream Subglacial Access Research Drilling (WISSARD) project was funded by National Science Foundation grants (0838933, 0838896, 0838941, 0839142, 0839059, 0838885, 0838855, 0838763, 0839107, 0838947, 0838854, 0838764, and 1142123) from the Division of Polar Programs. Partial support was also provided by funds from NSF award 1023233 (BC), the NSF's Graduate Research Fellowship Program (1247192; AA), NSF award 1115245 (JP), the American Association of University Women Dissertation Fellowship (TV-M), NSF's IGERT Program (0654336; AM), and NSF's Center for Dark Energy Biosphere Investigations (AM). Logistics were provided by the 139th Expeditionary Air lift Squadron of the New York Air National Guard, Kenn Borek Air, and by many dedicated individuals working as part of the Antarctic Support Contractor, managed by Lockheed-Martin. The drilling was directed by F. Rack and D. Duling (chief driller). D. Blythe, J. Burnett, C. Carpenter, D. Gibson, J. Lemery, A. Melby, and G. Roberts provided drill support at SLW. Computational analysis was conducted using the Louisiana State University high performance computing clusters.

\section{SUPPLEMENTARY MATERIAL}

The Supplementary Material for this article can be found online at: http://journal.frontiersin.org/article/10.3389/fmicb. 2016.01457

Blythe, D. S., Duling, D. V., and Gibson, D. E. (2014). Developing a hot-water drill system for the WISSARD project: 2. In situ water production. Ann. Glaciol. 55, 298-302. doi: 10.3189/2014AoG68A037

Boyd, E. S., Hamilton, T. L., Havig, J. R., Skidmore, M. L., and Shock, E. L. (2014). Chemolithotrophic primary production in a subglacial ecosystem. Appl. Environ. Microbiol. 80, 6146-6153. doi: 10.1128/AEM. 01956-14

Boyd, E. S., Lange, R. K., Mitchell, A. C., Havig, J. R., Hamilton, T. L., Lafrenière, M. J., et al. (2011). Diversity, abundance, and potential activity of nitrifying and nitrate-reducing microbial assemblages in a subglacial ecosystem. Appl. Environ. Microbiol. 77, 4778-4787. doi: 10.1128/AEM.00376-11

Boyd, E. S., Skidmore, M., Mitchell, A. C., Bakermans, C., and Peters, J. W. (2010). Methanogenesis in subglacial sediments. Envrion. Microbiol. Rep. 2, 685-692. doi: 10.1111/j.1758-2229.2010.00162.x

Burnett, J., Rack, F. R., Blythe, D., Swanson, P., Duling, D., Gibson, D., et al. (2014). Developing a hot-water drill system for the WISSARD project: 3 . Instrumentation and control systems. Ann. Glaciol. 55, 303-310.

Campbell, B. J., Yu, L., Heidelberg, J. F., and Kirchman, D. L. (2011). Activity of abundant and rare bacteria in a coastal ocean. Proc. Natl. Acad. Sci. U.S.A. 108, 12776-12781. doi: 10.1073/pnas.1101405108

Caporaso, J. G., Lauber, C. L., Walters, W. A., Berg-Lyons, D., Huntley, J., Fierer, N., et al. (2012). Ultra-high-throughput microbial community analysis 
on the Illumina HiSeq and MiSeq platforms. ISME J. 6, 1621-1624. doi: 10.1038/ismej.2012.8

Carter, S. P., Fricker, H. A., and Siegfried, M. R. (2013). Evidence of rapid subglacial water piracy under Whillans Ice Stream, West Antarctica. J. Glaciol. 59, 1147-1162. doi: 10.3189/2013JoG13J085

Cheng, S. M., and Foght, J. M. (2007). Cultivation-independent anddependent characterization of bacteria resident beneath John Evans Glacier. FEMS Microbiol. Ecol. 59, 318-330. doi: 10.1111/j.1574-6941.2006. 00267.x

Christianson, K., Jacobel, R. W., Horgan, H. J., Anandakrishnan, S., and Alley, R. B. (2012). Subglacial Lake Whillans-Ice-penetrating radar and GPS observations of a shallow active reservoir beneath a West Antarctic ice stream. Earth Planet. Sci. Lett. 331, 237-245. doi: 10.1016/j.epsl.2012.03.013

Christner, B. C., Mikucki, J. A., Foreman, C. M., Denson, J., and Priscu, J. C. (2005). Glacial ice cores: a model system for developing extraterrestrial decontamination protocols. Icarus 174, 572-584. doi: 10.1016/j.icarus.2004.10.027

Christner, B. C., Montross, G. G., and Priscu, J. C. (2012). Dissolved gases in frozen basal water from the NGRIP borehole: implications for biogeochemical processes beneath the Greenland Ice Sheet. Polar Biol. 35, 1735-1741. doi: 10.1007/s00300-012-1198-z

Christner, B. C., Mosley-Thompson, E., Thompson, L. G., and Reeve, J. N. (2001). Isolation of bacteria and $16 \mathrm{~S}$ rDNAs from Lake Vostok accretion ice. Environ. Microbiol. 3, 570-577. doi: 10.1046/j.1462-2920.2001.00226.x

Christner, B. C., Priscu, J. C., Achberger, A. M., Barbante, C., Carter, S. P., Christianson, K., et al. (2014). A microbial ecosystem beneath the West Antarctic ice sheet. Nature 512, 310-313. doi: 10.1038/nature13667

DeAngelis, K. M., Silver, W. L., Thompson, A. W., and Firestone, M. K. (2010). Microbial communities acclimate to recurring changes in soil redox potential status. Environ. Microbiol. 12, 3137-3149. doi: 10.1111/j.14622920.2010.02286.x

Dieser, M., Broemsen, E. L., Cameron, K. A., King, G. M., Achberger, A., Choquette, K., et al. (2014). Molecular and biogeochemical evidence for methane cycling beneath the western margin of the Greenland Ice Sheet. ISME J. 8, 2305-2316. doi: 10.1038/ismej.2014.59

Doran, P. T., Fritsen, C. H., Murray, A. E., Kenig, F., McKay, C. P., and Kyne, J. D. (2008). Entry approach into pristine ice-sealed lakes-Lake Vida, East Antarctica, a model ecosystem. Limnol. Oceanogr. Methods 6, 542-547. doi: 10.1007/s00203-009-0503-x

Doyle, S. (2015). Diversity and Activity of Bacteria in Basal Ice Environments. Ph.D. thesis, Louisiana State University, Baton Rouge, LA.

Edgar, R. C., Haas, B. J., Clemente, J. C., Quince, C., and Knight, R. (2011). UCHIME improves sensitivity and speed of chimera detection. Bioinformatics 27, 2194-2200. doi: 10.1093/bioinformatics/btr381

Finneran, K. T., Johnsen, C. V., and Lovley, D. R. (2003). Rhodoferax ferrireducens sp. nov., a psychrotolerant, facultatively anaerobic bacterium that oxidizes acetate with the reduction of Fe (III). Int. J. Syst. Evol. Microbiol. 53, 669-673. doi: 10.1099/ijs.0.02298-0

Fricker, H. A., Powell, R., Priscu, J., Tulaczyk, S., Anandakrishnan, S., Christner, B., et al. (2011). Siple coast subglacial aquatic environments: the whillans ice stream subglacial access research drilling project. Geophys. Monogr. Ser. 194, 199-219. doi: $10.1002 / 9781118670354 . c h 12$

Fricker, H. A., and Scambos, T. (2009). Connected subglacial lake activity on lower Mercer and Whillans ice streams, West Antarctica, 2003-2008. J. Glaciol. 55, 303-315. doi: 10.3189/002214309788608813

Fricker, H. A., Scambos, T., Bindschadler, R., and Padman, L. (2007). An active subglacial water system in West Antarctica mapped from space. Science 315, 1544-1548. doi: 10.1126/science. 1136897

Hamilton, T. L., Peters, J. W., Skidmore, M. L., and Boyd, E. S. (2013). Molecular evidence for an active endogenous microbiome beneath glacial ice. ISME J. 7 , 1402-1412. doi: 10.1038/ismej.2013.31

Harrold, Z. R., Skidmore, M. L., Hamilton, T. L., Desch, L., Amada, K., van Gelder, W., et al. (2016). Aerobic and anaerobic thiosulfate oxidation by a coldadapted, subglacial chemoautotroph. Appl. Environ. Microbiol. 82, 1486-1495. doi: 10.1128/AEM.03398-15

Hodson, T. O., Powell, R. D., Brachfeld, S. A., Tulaczyk, S., Scherer, R. P., and WISSARD Science Team (2016). Physical processes in Subglacial Lake
Whillans, West Antarctica: inferences from sediment cores. Earth Planet. Sci. Let. 444, 56-63. doi: 10.1016/j.epsl.2016.03.036

Hu, Z., Speth, D. R., Francoijs, K.-J., Quan, Z.-X., and Jetten, M. (2012). Metagenome analysis of a complex community reveals the metabolic blueprint of anammox bacterium "Candidatus Jettenia asiatica." Front. Microbiol. 3:366. doi: $10.3389 /$ fmicb.2012.00366

Jones, S. E., and Lennon, J. T. (2010). Dormancy contributes to the maintenance of microbial diversity. Proc. Natl. Acad. Sci. U.S.A. 107, 5881-5886. doi: 10.1073/pnas.0912765107

Karl, D., Bird, D., Björkman, K., Houlihan, T., Shackelford, R., and Tupas, L. (1999). Microorganisms in the accreted ice of Lake Vostok, Antarctica. Science 286, 2144-2147.

Kartal, B., Van Niftrik, L., Rattray, J., Van De Vossenberg, J. L., Schmid, M. C., Damsté, J. S., et al. (2008). Candidatus 'Brocadia fulgida': an autofluorescent anaerobic ammonium oxidizing bacterium. FEMS Microbiol. Ecol. 63, 46-55. doi: 10.1111/j.1574-6941.2007.00408.x

Kato, S., Krepski, S., Chan, C., Itoh, T., and Ohkuma, M. (2014). Ferriphaselus amnicola gen. nov., sp. nov., a neutrophilic, stalk-forming, iron-oxidizing bacterium isolated from an iron-rich groundwater seep. Int. J. Syst. Evol. Microbiol. 64, 921-925. doi: 10.1099/ijs.0.058487-0

Kim, S. J., Shin, S. C., Hong, S. G., Lee, Y. M., Lee, H., Lee, J., et al. (2012). Genome sequence of Janthinobacterium sp. strain PAMC 25724, isolated from alpine glacier cryoconite. J. Bacteriol. 194, 2096-2096. doi: 10.1128/JB.00096-12

Könneke, M., Bernhard, A. E., José, R., Walker, C. B., Waterbury, J. B., and Stahl, D. A. (2005). Isolation of an autotrophic ammonia-oxidizing marine archaeon. Nature 437, 543-546. doi: 10.1038/nature03911

Kuhn, E., Ichimura, A. S., Peng, V., Fritsen, C. H., Trubl, G., Doran, P. T., et al. (2014). Brine assemblages of ultrasmall microbial cells within the ice cover of Lake Vida, Antarctica. Appl. Environ. Microbiol. 80, 3687-3698. doi: 10.1128/AEM.00276-14

Lankiewicz, T. S., Cottrell, M. T., and Kirchman, D. L. (2015). Growth rates and rRNA content of four marine bacteria in pure cultures and in the Delaware estuary. ISME J. 10, 823-832. doi: 10.1038/ismej.2015.156

Lanoil, B., Skidmore, M., Priscu, J. C., Han, S., Foo, W., Vogel, S. W., et al. (2009). Bacteria beneath the West Antarctic ice sheet. Environ. Microbiol. 11, 609-615. doi: 10.1111/j.1462-2920.2008.01831.x

Lukin, V., and Bulat, S. (2011). "Vostok Subglacial Lake: details of Russian plans/activities for drilling and sampling," in Antarctic Subglacial Aquatic Environments, eds M. J. Siegert and M. C. Kennicutt (Washington, DC: American Geophysical Union), 187-197.

Martens-Habbena, W., Berube, P. M., Urakawa, H., José, R., and Stahl, D. A. (2009). Ammonia oxidation kinetics determine niche separation of nitrifying Archaea and Bacteria. Nature 461, 976-979. doi: 10.1038/nature08465

Michaud, A. B. (2016). Microbially Mediated Biogeochemical Cycles in Polar Ice Covered Lakes. Ph.D. thesis, Montana State University, Bozeman, MT.

Michaud, A. B., Skidmore, M. L., Mitchell, A. C., Vick-Majors, T. J., Barbante, C., Turetta, C., et al. (2016). Solute sources and geochemical processes in Subglacial Lake Whillans, West Antarctica. Geology 44, 347-350. doi: 10.1038/nature13667

Mikucki, J. A., and Priscu, J. C. (2007). Bacterial diversity associated with Blood Falls, a subglacial outflow from the Taylor Glacier, Antarctica. Appl. Environ. Microbiol. 73, 4029-4039. doi: 10.1128/AEM.01396-06

Mitchell, A. C., Lafrenière, M. J., Skidmore, M. L., and Boyd, E. S. (2013). Influence of bedrock mineral composition on microbial diversity in a subglacial environment. Geology 41, 855-858. doi: 10.1130/G34194.1

Oksanen, J., Blanchet, F. G., Kindt, R., Legendre, P., Minchin, P. R., O’Hara, R., et al. (2013). Package 'vegan.' R Packag. Ver. 254, 20-28.

Oswald, G. K. A., and Robin, G. D. Q. (1973). Lakes beneath the Antarctic ice sheet. Nature 245, 251-254. doi: 10.1038/245251a0

Palmer, S. J., Dowdeswell, J. A., Christoffersen, P., Young, D. A., Blankenship, D. D., Greenbaum, J. S., et al. (2013). Greenland subglacial lakes detected by radar. Geophys. Res. Lett. 40, 6154-6159. doi: 10.1038/ncomms9408

Pearce, D., Van der Gast, C., Lawley, B., and Ellis-Evans, J. (2003). Bacterioplankton community diversity in a maritime Antarctic lake, determined by culturedependent and culture-independent techniques. FEMS Microbiol. Ecol. 45, 59-70. doi: 10.1016/S0168-6496(03)00110-7

Priscu, J. C., Achberger, A. M., Cahoon, J. E., Christner, B. C., Edwards, R. L., Jones, W. L., et al. (2013). A microbiologically clean strategy for access to the 
Whillans Ice Stream subglacial environment. Antarct. Sci. 25, 637-647. doi: 10.1017/S0954102013000035

Priscu, J. C., Adams, E. E., Lyons, W. B., Voytek, M. A., Mogk, D. W., Brown, R. L., et al. (1999). Geomicrobiology of subglacial ice above Lake Vostok, Antarctica. Science 286, 2141-2144. doi: 10.1126/science.286.5447. 2141

Priscu, J. C., Tulaczyk, S., Studinger, M., Kennicutt, M., Christner, B. C., and Foreman, C. M. (2008). "Antarctic subglacial water: origin, evolution and ecology," in Polar Lakes and Rivers: Limnology of Arctic and Antarctic Aquatic Ecosystems, eds W. F. Vincent and J. Laybourn-Parry (Oxford: Oxford University Press), 119-135.

Pritchard, H., Ligtenberg, S., Fricker, H., Vaughan, D., Van den Broeke, M., and Padman, L. (2012). Antarctic ice-sheet loss driven by basal melting of ice shelves. Nature 484, 502-505. doi: 10.1038/nature10968

Pruesse, E., Peplies, J., and Glöckner, F. O. (2012). SINA: accurate high-throughput multiple sequence alignment of ribosomal RNA genes. Bioinformatics 28, $1823-$ 1829. doi: 10.1093/bioinformatics/bts 252

Purcell, A. M., Mikucki, J. A., Achberger, A. M., Alekhina, I. A., Barbante, C., Christner, B. C., et al. (2014). Microbial sulfur transformations in sediments from Subglacial Lake Whillans. Front. Microbiol. 5:594. doi: 10.3389/fmicb.2014.00594

Qin, W., Amin, S. A., Martens-Habbena, W., Walker, C. B., Urakawa, H., Devol, A. H., et al. (2014). Marine ammonia-oxidizing archaeal isolates display obligate mixotrophy and wide ecotypic variation. Proc. Natl. Acad. Sci. U.S.A. 111, 12504-12509. doi: 10.1073/pnas.1324115111

R Core Team (2015). R: A Language and Environment for Statistical Computing [Internet]. Vienna: R Foundation for Statistical Computing.

Rack, F. R. (2016). Enabling clean access into Subglacial Lake Whillans: development and use of the WISSARD hot water drill system. Philos. Trans. A Math. Phys. Eng. Sci. 374:20140305. doi: 10.1098/rsta. 2014.0305

Rack, F. R., Duling, D., Blythe, D., Burnett, J., Gibson, D., Roberts, G., et al. (2014). Developing a hot-water drill system for the WISSARD project: 1 . Basic drill system components and design. Ann. Glaciol. 55, 285-297. doi: 10.3189/2014AoG68A031

Roberts, D. (2007). labdsv: Ordination and Multivariate Analysis for Ecology. $R$ Package Version 1.

Ross, N., Siegert, M., Rivera, A., Bentley, M., Blake, D., Capper, L., et al. (2011). "Ellsworth Subglacial Lake, West Antarctica: a review of its history and recent field campaigns," in Antarctic Subglacial Aquatic Environments, eds M. J. Siegert and M. C. Kennicutt (Washington, DC: American Geophysical Union), 221-233.

Salter, S. J., Cox, M. J., Turek, E. M., Calus, S. T., Cookson, W. O., Moffatt, M. F., et al. (2014). Reagent and laboratory contamination can critically impact sequence-based microbiome analyses. BMC Biol. 12:87. doi: 10.1186/s12915014-0087-z

Schloss, P. D., Westcott, S. L., Ryabin, T., Hall, J. R., Hartmann, M., Hollister, E. B., et al. (2009). Introducing mothur: open-source, platformindependent, community-supported software for describing and comparing microbial communities. Appl. Environ. Microbiol. 75, 7537-7541. doi: 10.1128/AEM.01541-09

Siegert, M. J., Clarke, R. J., Mowlem, M., Ross, N., Hill, C. S., Tait, A., et al. (2012). Clean access, measurement, and sampling of Ellsworth Subglacial Lake: a method for exploring deep Antarctic subglacial lake environments. Rev. Geophys. 50:RG1003. doi: 10.1029/2011RG000361

Siegfried, M. R., Fricker, H. A., Carter, S. P., and Tulaczyk, S. (2016). Episodic ice velocity fluctuations triggered by a subglacial flood in West Antarctica. Geophys. Res. Lett. 43:2640. doi: 10.1002/2016GL067758

Skidmore, M. (2011). "Microbial communities in Antarctic subglacial aquatic environments (SAE)," in Antarctic Subglacial Aquatic Environments, eds M. J. Siegert and M. C. Kennicutt (Washington, DC: American Geophysical Union), 61-68.
Skidmore, M., Anderson, S. P., Sharp, M., Foght, J., and Lanoil, B. D. (2005) Comparison of microbial community compositions of two subglacial environments reveals a possible role for microbes in chemical weathering processes. Appl. Environ. Microbiol. 71, 6986-6997. doi: 10.1128/AEM.71.11.69866997.2005

Skidmore, M., Tranter, M., Tulaczyk, S., and Lanoil, B. (2010). Hydrochemistry of ice stream beds-evaporitic or microbial effects? Hydrol. Process. 24, 517-523.

Smith, B. E., Fricker, H. A., Joughin, I. R., and Tulaczyk, S. (2009). An inventory of active subglacial lakes in Antarctica detected by ICESat (2003-2008). J. Glaciol. 55, 573-595. doi: 10.3189/002214309789470879

Steven, B., Chen, M. Q., Greer, C. W., Whyte, L. G., and Niederberger, T. D. (2008). Tumebacillus permanentifrigoris gen. nov., sp. nov., an aerobic, spore-forming bacterium isolated from Canadian high Arctic permafrost. Int. J. Syst. Evol. Microbiol. 58, 1497-1501. doi: 10.1099/ijs.0.65101-0

Stibal, M., Hasan, F., Wadham, J. L., Sharp, M. J., and Anesio, A. M. (2012a). Prokaryotic diversity in sediments beneath two polar glaciers with contrasting organic carbon substrates. Extremophiles 16, 255-265. doi: 10.1007/s00792-0110426-8

Stibal, M., Wadham, J. L., Lis, G. P., Telling, J., Pancost, R. D., Dubnick, A., et al. (2012b). Methanogenic potential of Arctic and Antarctic subglacial environments with contrasting organic carbon sources. Glob. Change Biol. 18, 3332-3345. doi: 10.1111/j.1365-2486.2012.02763.x

Stief, P., Kamp, A., Thamdrup, B., and Glud, R. N. (2016). Anaerobic nitrogen turnover by sinking diatom aggregates at varying ambient oxygen levels. Front. Microbiol. 7:98. doi: 10.3389/fmicb.2016.00098

Studinger, M., Bell, R. E., Blankenship, D. D., Finn, C. A., Arko, R. A., Morse, D. L., et al. (2001). Subglacial sediments: a regional geological template for ice flow in West Antarctica. Geophys. Res. Lett. 28, 3493-3496. doi: 10.1126/sciadv.1500093

Tulaczyk, S., Mikucki, J. A., Siegfried, M. R., Priscu, J. C., Barcheck, C. G., Beem, L. H., et al. (2014). WISSARD at Subglacial Lake Whillans, West Antarctica: scientific operations and initial observations. Ann. Glaciol. 55, 51-58. doi: 10.3189/2014AoG65A009

van Kessel, M. A., Speth, D. R., Albertsen, M., Nielsen, P. H., den Camp, H. J. O., Kartal, B., et al. (2015). Complete nitrification by a single microorganism. Nature 528, 555-559. doi: 10.1038/nature16459

Vick-Majors, T. J. (2016). Biogeochemical Processes in Antarctic Aquatic Environments: Linkages and Limitations. Ph.D. thesis, Montana State University, Bozeman, MT.

Wadham, J., Arndt, S., Tulaczyk, S., Stibal, M., Tranter, M., Telling, J., et al. (2012). Potential methane reservoirs beneath Antarctica. Nature 488, 633-637. doi: 10.1038 /nature11374

Wadham, J., Tranter, M., Tulaczyk, S., and Sharp, M. (2008). Subglacial methanogenesis: a potential climatic amplifier? Glob. Biogeochem. Cycles 22:GB2021. doi: 10.1029/2007GB002951

Whitman, W. B., Coleman, D. C., and Wiebe, W. J. (1998). Prokaryotes: the unseen majority. Proc. Natl. Acad. Sci. U.S.A. 95, 6578-6583. doi: 10.1073/pnas.95.12.6578

Wright, A., and Siegert, M. (2012). A fourth inventory of Antarctic subglacial lakes. Antarct. Sci. 24, 659-664. doi: 10.1017/S095410201200048X

Conflict of Interest Statement: The authors declare that the research was conducted in the absence of any commercial or financial relationships that could be construed as a potential conflict of interest.

Copyright (C) 2016 Achberger, Christner, Michaud, Priscu, Skidmore, Vick-Majors and the WISSARD Science Team. This is an open-access article distributed under the terms of the Creative Commons Attribution License (CC BY). The use, distribution or reproduction in other forums is permitted, provided the original author(s) or licensor are credited and that the original publication in this journal is cited, in accordance with accepted academic practice. No use, distribution or reproduction is permitted which does not comply with these terms. 